\title{
Study of the Vulnerability of Coastal Areas of the Algerian Basin with the GIS
}

\author{
M. K. Mihoubi, R. Belkessa, and M. A. Latreche
}

\begin{abstract}
The Bay of Algiers is of a strategic, economic, and social, it is located in the heart of the Algerian capital, where the population density is high and many factories and commercial activities making it vulnerable to the pollution. Particularly along the coast, in addition to climate change, all this leads us to study their impact on the coast of Bay of Algiers, and exposure to risks of erosion and seawater intrusion. The aim of the work is the perception of vulnerable coastal areas by determining the coastal vulnerability index (CVI) at Bay of Algiers, based on physical, geomorphological and hydrodynamic factors, coupled a study of groundwater vulnerability to risks bevel saline particular endangered areas.

These results obtained enable to project the future maps from the request processing on the state of the coastal system using the Geographical Information System (GIS). Landmark decisive tools to provide preventive and curative solutions to coastal systems for better coastal protection particular to estuarine areas, privileged place for exchange of sediment transport.

The results of the study helped to locate areas of high vulnerability to moderate eastern bay of Algiers by the ICV index varying from 8 to 14 . These values are still increasing in the medium to long term if no Compensation by protective structures unsupported consideration.
\end{abstract}

Index Terms-Bay of Algiers, coastal vulnerability, pollution, coast line, DRASTIC, CVI.

\section{INTRODUCTION}

The coastline is a complex and sensitive environment, actually, it combines two different areas, the land and sea side, on either side affects the other over and above its role as a living space, which is under pressure to order and anthropogenic climatic. These disruption and lead to numerous risks to the coastal system. Order to protect our environment, it is essential to seat an effective and sustainable approach to the management of coastal areas vulnerable.

In the marine environment, flow of the water is responsible for sediment transport, where sediment particles can be transported in different ways. On this action, the morphology of the bottom will play an important role in the sediment transport, thus causing sediment transport modes namely: According to the work [1], the bed load transport is the share of total transport which the grains are always more or less in contact with the bottom during transport [2], the flow is slow or the particles are heavy.

Manuscript received March 3, 2014; revised May 5, 2014.

M. K. Mihoubi and M. A. Latreche are with Laboratory Mobilization and Recovery of Water Resource (LMVR-ENSH), National School for Hydraulics (ENSH), Algeria (e-mail: mihkam@ensh.dz).

R. Belkessa is with National School for Marine Sciences and Coastal Management (ENSSMAL). Algeria (e-mail: belkessarabah@yahoo.fr).
Transport sediments suspension concerns that ship without being in contact with the bottom, and are lifted and moved in the water column due turbulent vertical velocities in the fluid.

It is independent of transport by saltation, the particles in suspension can traverse long distances at speeds of fall is offset by upward fluid circulations.

The transport by the sheet flow is located in the area near the bottom, or the particles move in a disorganized way, when currents are intense and relatively coarse sediments. The flow sheet is a sedimentary layer that moves horizontally on the order of a few centimeters in height. This sediment transport generates a accretion and erosion factors having an important role in hydro-sedimentary processes that contribute enormously in the evolution of the coastline at scales of a time and space very varied [3]. According to the obliquity and direction of waves play an important role in sediment transport at the shoreline by the orbital motion of the waves [4].

Sediment transport can be done in a more complex way by the currents induced by waves contributing to the movement of the particles and the formation of the bars also known as sedimentary dunes including the transport direction is longitudinal or transversal [5] Regarding estuaries and river mouths, being the area of interaction of marine and river waters seats exchanges of individual particles in suspension; Thus shaping a morphological structure of estuarine landscapes. It is appropriate clear that the estuary differs from the mouth through the influence of the tide. According to the hydrodynamic parameters, count mouths dominated by fluvial inputs and those dominated by contributions from waves [6]. They are also characterized by two movements of water masses from the dynamics of waves and currents.

\section{Methodology}

\section{A. Coastal Vulnerability Index}

The importance of the coastline in the development of tourism, industrial and petrochemical while ensuring sustainable development in the coastal ecosystem makes us more than ever to have decision support for integrated management of the coastal system tools. Geographical information systems (GIS) can be a tool to help define the issues and future scenarios coastal processes. Taking into account the sensitivity of the environment and the risks they run, thus leading to highlight vulnerable areas.

The physical vulnerability [7] of a coastal area expresses the degree and risk of physical changes that the middle can undergo.

A title, such as floods, erosion and shoreline recedes, the destabilization of coastal dunes, physico-chemical water 
degradation, silting of ports and coastal facilities. It expresses the degree to which a system is susceptible to, or be adversely affected by the adverse effects of climate change, including climate variability and extremes.

Knowing that forecasting studies based on climate models is agreeing in their majorities on important and negative impacts of climate change by a magnitude of erosion and decline of coastline over the next century.

Analysis of the coastline is based upon a set tapes or segments. Each coastal segment will have a responsibility to respond unfavorably to a risk, the so-called vulnerability; it is defined by the coastal vulnerability index (CVI) and defined by Gornitz et al. 1994 [8], an empirical method widely used by United States Geological Survey (USGS). It is appropriate remembered that this index can be used to identify areas risqueet those most vulnerable to a rise in sea level from the simultaneous combination of six variables related to risk, according to the following relationship:

$$
\mathrm{ICV}=\sqrt{\frac{1}{6}\left(a * b * c * d * e^{*} f\right)}
$$

where, $a$ : geomorphological variable, $b$ : coastal slope, $c$ : relative rate of rise of sea level, $d$ : rate of decline of the coastline, $e$ : average tidal range, $f$ : average wave height.

Formulation and Gornitz et al., 1994 [8], closes six variables because of their use in risk measurement for the coast. They are classified according to a linear scale of 1 to 5, and in an order of increasing vulnerability due to rising sea level: a value of 1 would correspond to a very low risk and 5 as high There are four classes of risk are determined as follows:

1) Index low: low risk are less than 10 .

2) Moderate Index: moderate risk range between 10 and 20 .

3) High Index: high risk are between 20 and 30.

4) Index very high: very high risk are greater than 30 .

\section{B. DRASTIC Vulnerability Index from an Aquifer}

Vulnérabilté DRASTIC index was developed in USA by the "National Water Well Association" (NWWA) in collaboration with "The U.S. Environmental Protection Agency" (EPA) [9]. It provides a model to assess the potential for contamination of aquifers independently of the type of pollutant and that takes into account most of the hydrogeologic factors that affect and control the flow of groundwater.

This index has the great advantage of being very easily integrated in a GIS. The acronym DRASTIC is derived from the initials of the seven physiographic and hydrogeological settings used in the model. The DRASTIC vulnerability index, given by the weighted sum for each parameter, each partial index is derived by multiplying its coast by its relative weight according to the following formulation sub-indices:

$\mathrm{ID}=(\mathrm{Dc} . \mathrm{Dp})+(\mathrm{Rc} . \mathrm{Rp})+(\mathrm{Ac} . \mathrm{Ap})+(\mathrm{Sc} . \mathrm{Sp})+(\mathrm{Tc} . \mathrm{Tp})+(\mathrm{Ic} \cdot \mathrm{Ip})+(\mathrm{Cc} . \mathrm{Cp})$

where: Dc: Coast parameter D; Dp: weight parameter D.

The DRASTIC index spreads over the whole range from 23 to 226 , the risk of groundwater contamination increases with the value of this index, and vulnerability to pollution is higher for higher ribs. Several methods have been developed indexed by DRASTIC principle which, for example:

Aquifer Vulnerability Index AVI method (Van Stempvoort et al, 1993) [10], developed in Canada considers: (1) the depth and conductivity of each stratigraphic layers situated above the groundwater level and (2) the hydraulic gradient.

\section{Study Area}

\section{1) The database}

Inventory data collection and consist of: files piezometers and drilling of the study area, files rates decline the shores of the Bay of Algiers, data relating to sea level rise in the Mediterranean and the amplitude of the tide. Other cartographic data were analyzed such as: maps of wave heights at the hydrogeological and bathymetric Bay of Algiers, soil maps, geological, study areas.

Other data were gathered during inventory have been integrated from a digitization and conversion to part of the system database.

GIS is used MapInfo Professional 8.0, the software that we have more compatible implementation debase our data system, and develop critical operations processed by three cards software: timing, digitizing and thematic analysis queries.

Therefore it is possible analyzes a single variable (classes, individual values, dot density, proportional symbols) or thematic multivariate analyzes (Fig. 1)

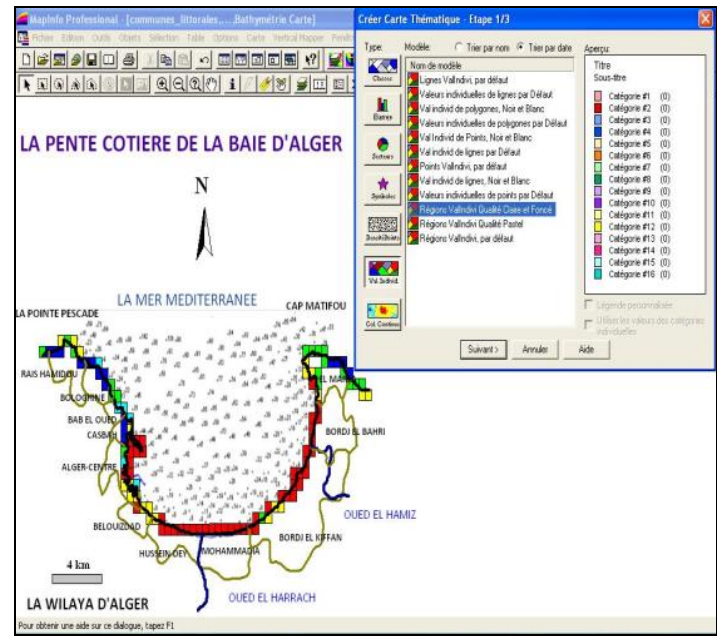

Fig. 1. Card Processing according to vulnerability through meaningful colors.

In our study area, to calculate the coastal vulnerability index, and apply the DRASTIC method, we made a mesh along the coast of the Bay of Algiers, from the common Raiis Hamidou (tip Pescade) to the town of El Marsa (Matifou) and at the surface of the vulnerable zone (the municipalities of: Hussein Dey, Mohammedia, Bordj El Kiffan, Bordj El Bahri and).

\section{2) The treatment}

The treatment area consists of a square of $500 \mathrm{~m}$ side, each cell has its data, and each has a given level of vulnerability, the data type is a map (geographical, geological, hydrogeological...), a aerial photography, an Excel 
spreadsheet, or a value directly attached. The establishment of the final card is dealt to the superposition of tables, each table represents a parameter responsibility to determine the risk of erosion (down the coast), or pollution (contamination of water) (Fig. 2).

TABLE I: CLASSIFICATION OF THE COASTAL SLOPE FOR CVI (THIELER AND HAMMAR-KLOSE, 1999)

\begin{tabular}{|l|l|l|l|l|l|}
\hline \multirow{2}{*}{} & \multicolumn{5}{|c|}{ Class of coastal vulnerability index(CVI) } \\
\cline { 2 - 6 } & $\begin{array}{l}\text { Very } \\
\text { Low }\end{array}$ & Low & Moderate & High & Very High \\
\cline { 2 - 6 } & 1 & 2 & 3 & 4 & 5 \\
\hline $\begin{array}{l}\text { Coastal } \\
\text { slope }(\%)\end{array}$ & $>12$ & $12-9$ & $9-6$ & $6-3$ & $<3$ \\
\hline
\end{tabular}

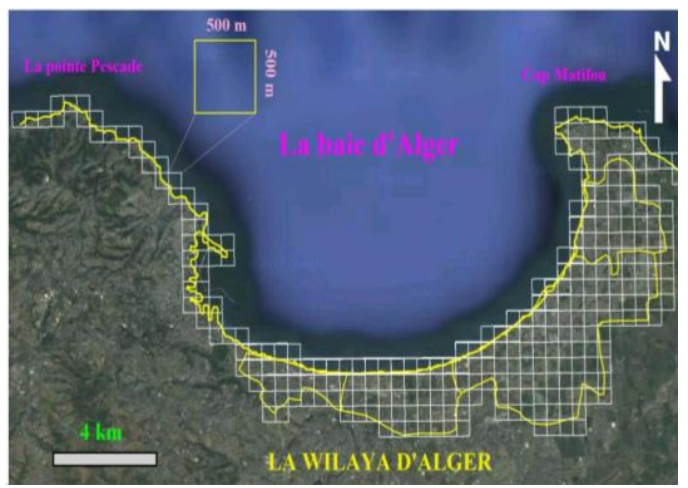

Fig. 2. Mesh at the coastal area of Algiers.

\section{RESUlTS AND DisCUSSION}

Morphological formation of the Bay of Algiers consists of three different types: From the town center Raïs Hamidou to Algiers, and the town of El Marsa Miocene and older rocks. The city of Belouizdad until Oued El Harrach outlet: dune formations consolidated. The right bank of Oued El Harrach to the town of Bordj el Bahri (the plain of eastern Mitija) alluvium Mitija. Vulnerability almost very low at both ends of the bay, but the hollow of the bay of Algiers is very vulnerable, we also note that the risk factor is moderate along the shore of Bordj El Bordj El Bahri and Kiffan .

According to the morphological appearance of the Bay of Algiers (Fig. 3), the phenomenon of erosion threatens much of the coastline, and it can lead to the loss of some beaches.

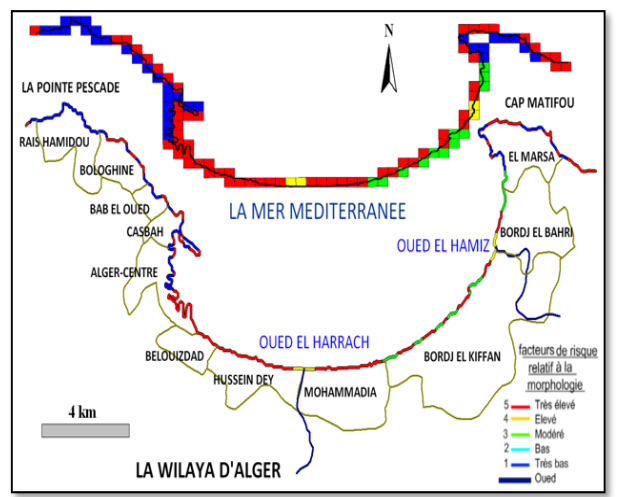

Fig. 3. Coastal vulnerability morphology according to the Bay of Algiers.

Regarding the Bay coasts of Algiers, both ends of the bay have a generally higher slope with maximum values are $23 \%$ at the common Raïs Hamidou Bologhine, ET19\% in the municipality of El Marsa.
In this case, there was a gentle slope in the hollow of the bay which varies between 1 and $2.5 \%$, but the minimum value is the town of Bordj El Bahri (0.6\%). The establishment of classes was performed on the basis of work Thieler and Hammar-Klose (1999) [10] on the CVI (Fig. 4).

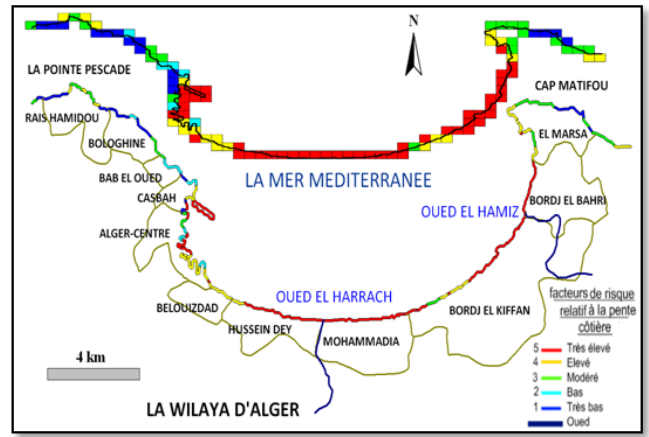

Fig. 4. Coastal Vulnerability according to the coastal slope of the bay of Algiers.

The rate climbed from sea to climate change and the increase in global temperature.

Bay of Algiers located in the western part of the Mediterranean Sea, the rate of rise of sea level does not exceed the value of $1.1 \mathrm{~mm} /$ year, this value remains below $1,8 \mathrm{~mm}$ / year where the CVI index is at its lowest value (Fig. $5)$.

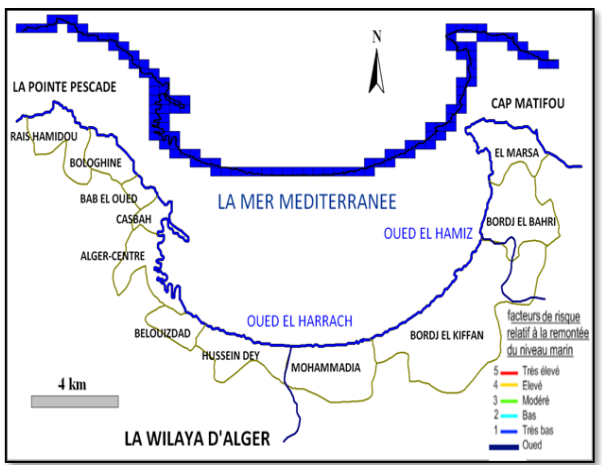

Fig. 5. Coastal vulnerability according to sea level rise for the Bay of Algiers.

Most of the shores of the Bay of Algiers is recorded a moderate decline, except the sablettes beach, west of the Algiers port has experienced accretion, we also note a high regression beaches of the town of Bordj El Kiffan, and at the town of Mohammedia east of the Bay of Algiers (Fig. 6).

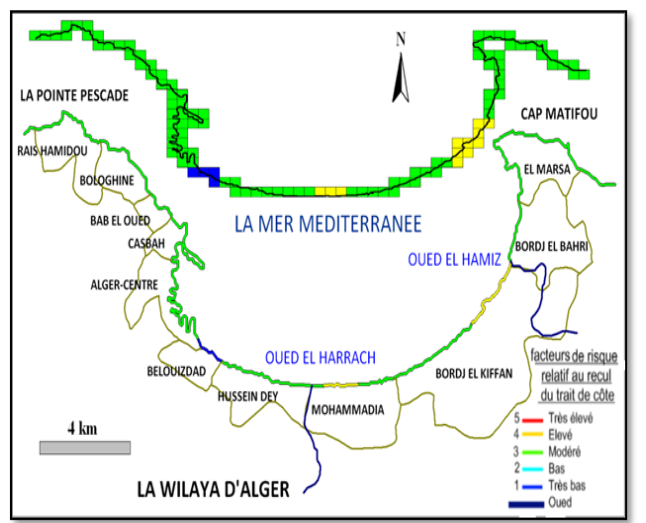

Fig. 6. Coastal Vulnerability according to the evolution of the coastline for the Bay of Algiers. 
As the tide in the Mediterranean basin is micro-tidal type because it at allow amplitude of the order of $0,40 \mathrm{~m}$, a very high value according CVI. Fig. 7 illustrates the vulnerability according to the average height of the waves on the Bay of Algiers.

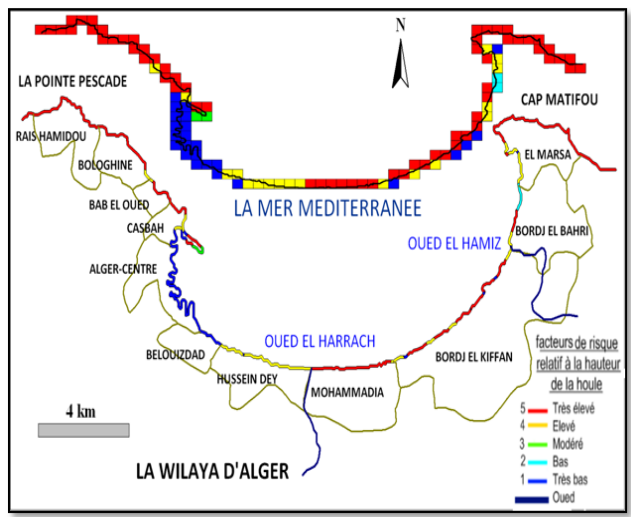

Fig. 7. Coastal Vulnerability according to the average wave height for the Bay of Algiers.

The combinations of all risk have identified the coastal vulnerability index in the form of Gornitz et al. (1994) [8]. This index can detect the most sensitive areas and the factors responsible for risk. The values of this index we calculated vary between 1.6 and 20.4 with an average value of 10.4, and the median is 8.3 .

Using the method of lines quartiles $(25 \%, 50 \%, 75 \%$, $100 \%$ ) and by visual inspection of the data, the results of the ICV is divided into four categories, if the lower ICV 6 the risk is low, and moderate between 6 from 1 to 8.3 , and in the range of 8.3 to 14 the risk is high if more than 14 risk they say is very high. On the map of coastal vulnerability, we gave each risk class a significant color (Fig. 8).

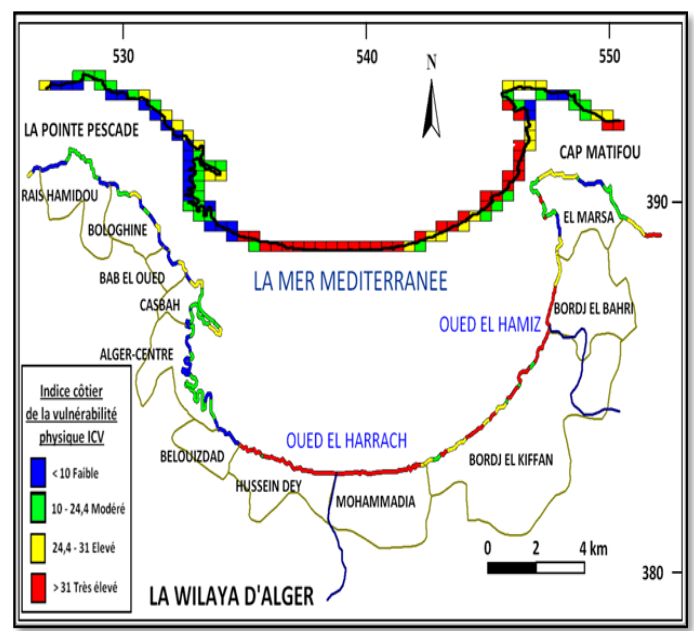

Fig. 8. Coastal vulnerability index (CVI) for the coast of the bay of Algiers.

It may be noted that the vulnerability at the shores of Hussein Dey, Mohammedia, and much of Bordj El Bordj El Bahri Kiffan and is very high, this is mainly due to the morphology of these areas. The structure of the beaches here is sandy and alluvial, where the slope is very weak, which makes the coast more vulnerable to soil erosion and flooding, especially at the mouth of Oued El Harrach and Wadi El Hamiz due to the lack of effective protection and development (Fig. 9).

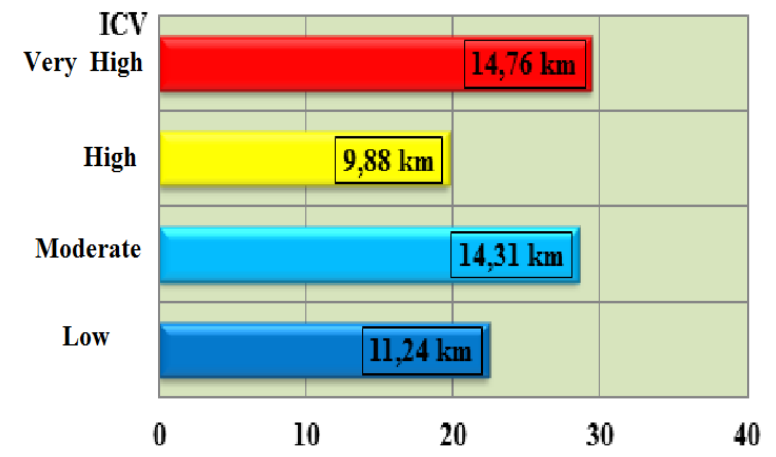

Fig. 9. Percent of the coastline of Bay of Algiers for every degree of physical vulnerability.

The east and west of the Bay of Algiers regions are less affected because its morphological structure is rocky, and its slope generally higher, despite the intensity of the waves in these areas, but the vulnerability is almost moderate, except some shores experiencing low vulnerability (Raïs Hamidou, El Marsa, and at the port of Algiers).

\section{CONLUSION}

To the coast of the Bay of Algiers, the most vulnerable areas are those with the lowest slopes, which mainly consist of large sandy areas, and alluvial, especially the municipalities of: Hussein Dey, Mohammedia, Bordj el Kiffan and Bordj el Bahri. The sea level rises by low speed (not more than $1.1 \mathrm{~mm} /$ year), and the line of the coast regressed moderately along the coast, with a few exceptions.

Regarding the hydrodynamic factors, there has been very high because the average amplitude of the tide (microtidal) risk, and a variation in intensity of the wave, since our area as a bay, and port facilities in the port of Algiers is an obstacle to the energy dissipation due to wave breaking.

The Bay of Algiers, has a very high potential vulnerability, almost at the shores of Hussein Dey, Mohammedia, Bordj el Kiffan and Bordj el Bahri percentage about 30\% along the coast, and almost $20 \%$ are areas of high vulnerability, moderate risk on $30 \%$ of the coastline, and remaining $20 \%$ is a low risk outstanding at both ends of the Bay of Algiers in natural rocky areas.

\section{REFERENCES}

[1] J. Fredsoe and R. Deigaard, "Mechanics of coastal sediment transport advanced series on ocean engineering," World Scientific, Singapore vol. 3, pp. 130-149, 1992.

[2] V. Marieu, "Dynamics modeling of sediment ripples generated by waves," PhD dissertation, Bordeaux I University, 2007.

[3] R. L. Soulsby, Dynamics of Marine Sands, London: Thomas Telford Publication, ch. 8 and 9, pp. 129-166, 1997.

[4] R. Bonnefille, Maritime Hydraulic Courses, 3rd ed. Masson, Ed. 1992, pp. 18-99.

[5] B. Casstelle, "Modelling the hydrodynamic sediment over the sand bars on subject to wave action: application to the Aquitaine coast," PhD dissertation, Bordeaux I University, 2004.

[6] L. D. Wright, "Sediment transport and deposition at river mouths: A synthesis," Geology Society, Am. Bull., vol. 88, pp. 857-868, 1977.

[7] I. Mendizabal and P. J. Stuyfzand, "Quantify ing the vulnerability of weil fields towards anthropogenic pollution: The Netherlands as an example," Journal of Hydrology, vol. 398, pp. 260-276, 2011.

[8] V. M. Gornitz, R. C. Daniels, T. W. White, and K. R. Birdwell, "The development of a coastal risk assessment database: Vulnerability to sea-level rise in the U.S. southeast," Journal of Coastal Research, vol 12 , pp. 327-338, 1994 
[9] L. Aller, T. Bennett, J. H. Lehr, R J. Petty, and G. Hackett, "Drastic: A standardized system for evaluating ground water pollution potential using hydrogeologie settings," United States, Environmental protection Agency, June 1987.

[10] E. R. Thieler and E. S. Hammar-Klose, "National assessment of coastal vulnerability to sea-level rise," Preliminary Results for the U.S. Atlantic Coast, U.S. Geological Survey Open-File Report, pp. 99-593, 1999.

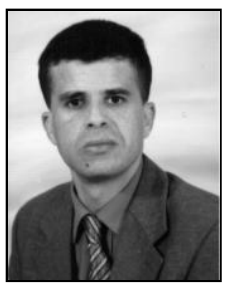

M. K. Mihoubi was born in 1996 in Algiers. In 1991, he was an engineer and a magister of engineering water. He had the $\mathrm{PhD}$ degree in hydraulic at the National Polytechnic School of Algiers in 2008. He is an assistant professor at the National School for Hydraulics "École Nationale Supérieure d'Hydraulique" (ENSH), Blida. He is the head of Hydraulic Engineering Departement. He is the author of numerous publications and contributions on sediment transport coastal and measurement of the velocity profile in the swash zone with Utrasonic Doppler Velocimetry (UDV).

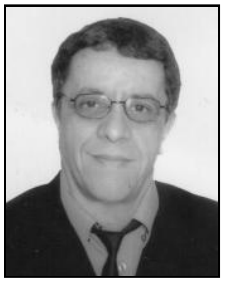

R. Belkessa was born in 1957. His is a professor at the Superior National School of Marine Sciences and Coastal Management "Ecole Nationale Superieure des sciences de la Mer et de l'Aménagement du littoral" (ENSSMAL), Algiers. He has several research of the field of study of vulnerability. He is the director of a national research project on the prevention of natural disasters and protection against major risks Bay of Algiers. 